\title{
BLUE ECONOMY: TECHNOLOGIES FOR SUSTAINABLE DEVELOPMENT
}

Nicholas Kathijotes ${ }^{1}$

Dali Sekhniashvili ${ }^{2}$

UDK: 502.171:546.212

DOI:10.14415/konferencijaGFS2017.066

Summary: The aim of Blue Economy model is to shift society from scarcity to abundance -based on what we have, and to start tackling issues that cause environmental and related problems through new and novel ways. Inland and coastal waters are investigated as 'water resources' that can contribute to the production of sustainable energies. In water reuse, the energy contained in wastewater is also examined in order to contribute to the understanding of the water/energy relationship. Energy is needed for water cycle management; water added needed for energy production and water reuse can help to save both. Biogas production, being an important green energy issue is also examined under the scope of wastewater treatment. Significant energy savings can be achieved on major components of an 'efficient' wastewater treatment plant by applying novel blue economy principles. Zones where energy efficiency can be improved are explained. Marine based renewable energies are outlined based on coastal blue potentials and future world energy needs-provided that conventional energy sources are approaching exhaustion. Other general quality issues in coastal environments are presented and examined within the framework of the blue economy principle and thus suggesting actual novel sustainable management techniques.

Keywords: Blue economy; sustainable energy; water resources; wastewater treatment

\section{INTRODUCTION}

In conceptualizing 'Blue Economy', we can say that 'Blue economy' refers to the new system of Green Economy that interweaves creative neo-science and associated technologies. At the same time, the environmental imperative to decarbonize the energy system, has driven unprecedented interest in marine renewable energy (MRE) resources. MRE technologies, including wave and tidal energy, have been identified by the EU as one of the five key activities that can advance the Blue Economy, delivering sustainable growth and creating new jobs [5].

The Water-Energy Nexus aspect, explores the role that policy and innovation could play in order incentivize a more efficient use of water and energy resources in different sectors and/or regions of the world. Many of our technical processes of harnessing, extracting,

${ }^{1}$ Nicholas Kathijotes, Prof. Dr., University of Nicosia, Faculty of Engineering, POB 24005 Nicosia, Cyprus CY1700, tel: 0035796716550 e-mail: kathijotes.n@unic.ac.cy

${ }^{2}$ Dali Sekhniashvili, Prof. Dr. Georgian Technical University, Faculty of Engineering Economics, Tbilisi, Georgia 
and producing energy utilize water. Similarly, water extraction, treatment, distribution, and disposal processes consume energy. The effects of global warming and climate change, amplify the need for managing energy and water along with nutrients in an integrated system adapted to the growing urban development.

\section{RESULTS AND DISCUSSION}

Energy is mainly produced from fossil (oil, gas, and coal) and nuclear energies which have limited reserves. Globally, we currently produce about 10 billion toe (ton of oil equivalent). The total global petroleum consumption is still increasing due to intensified energy consumption. In 2007, there were 806 million cars and light trucks [12] which is expected to increase up to 1.3 billion by 2030 and 2 billion by 2050 [13]. Currently, onefifth of the global $\mathrm{CO} 2$ emission is due to transportation and trucking. It is critical to realize the negative impacts imparted on the global enviro- nment by fossil fuels that has drifted the exploitation of alternate fuels. The green replacement of fossil based petro fuel is the trending strategy that has gained much attention from scientists all over the world.

Due to the economic development of nations, a 50 to $300 \%$ increase in consumption is expected by 2050 .

\section{Marine-Based Blue Energy}

Ocean energy lay dormant for decades following the easing of the oil crisis, but a new era of climate change, renewable energy and the Blue Economy is driving renewed interest and development. In this context, a range of scholarship has emerged, focusing initially on resource assessment, device design, and environmental impacts. This focus is beginning to broaden as a commercial-scale industry develops.

It is a priority to reduce the use of fossil fuels and simultaneously use renewable energy including solar energy, wind power, wave energy, tidal energy, Ocean Thermal Energy Conversion (OTEC) and biofuel from marine algae and sea grasses. Marine energies have the potential to enhance the efficiency of harvesting the energy resource, minimize landuse requirements of the power sector and reduce the greenhouse gas emissions [2]. Ocean energy technologies, utilising waves and tides to generate electricity are now attracting considerable interest and investment [6]. As with other novel offshore activities, ocean energy is bringing its own unique challenges to marine govern- ance frameworks [7] Extreme care should be given to the prevention or interference with natural processes. Interest in ocean energy is especially high in Europe. The European Commission has recently developed an action plan to support the ocean energy sector, convening an Ocean Energy Forum to bring together stakeholders and develop solutions. This will feed into a strategic roadmap, providing an agreed blueprint for action. There is potential for a European Industrial Initiative to be developed during a second phase (2017-2020). Ocean Energy Europe, an industry association, has concurrently convened a Technology and Innovation Platform for Ocean Energy, the primary focus of which is to foster a broad consensus on priorities for technological innovation. The UK, and Scotland in particular, finds itself at the vanguard of this new industry, as ocean energy enjoys a combi- nation of political support, significant resources and technical expertise [8,9]. Marine macroalgae is also a potential biomass for biofuel production because of their higher productivity rates 
Contemporary achievements in civil engineering 21. April 2017. Subotica, SERBIA

than terrestrial biomass such as corn and switch grass [10]. Annual biomass production of macroalgae is too high [11] and the ease degree of maintenance in large scale cultivation of marine seaweed serves as a key factor for using marine macroalgae as biofuel feedstock.

\section{Energy cost for Water}

We then need to increase 'energy efficiency' which entails reducing and optimizing the energy consumption of a process while maintaining its efficiency. The possibility of producing green energy, and using it directly to power facilities or supplement energy to grids, reduces greenhouse gas emissions and carbon footprint of plants, producing great cuts on energy costs. Conventional water treatment, for producing drinking water with the deterioration of resources is no longer inexpensive. Indicative costs range from $30 \mathrm{Wh} / \mathrm{m} 3$ for classic treatment to $120 \mathrm{Wh} / \mathrm{m}^{3}$ for activated carbon and ozone, and to $200 \mathrm{Wh} / \mathrm{m}^{3}$ for membrane ultrafiltration. A key point for energy optimization in membrane technologies, is the design of pretreatments in order to reduce waste discharge from membrane treatment. General desalination water costs $3.5-5 \mathrm{KWh} / \mathrm{m}^{3}$, even though high efficiency plants like Ashkelon in Israel has a cost of $2.9 \mathrm{KWh} / \mathrm{m}^{3}$ [4]. Treated wastewater 1.2 $\mathrm{KWh} / \mathrm{m}^{3}$, with higher efficiency plants like Strass in Austria, achieving a very low cost of $0.35 \mathrm{KWh} / \mathrm{m}^{3}$, but also producing electricity achieving self-efficiency [3]. Rainwater costs only $0.0012 \mathrm{KWh} / \mathrm{m}^{3}$ basically attributed to pumping needs

\section{Epilogue with suggestions for energy gaining from wastewater treatment}

The aim then in optimizing the energy from a treatment plant is threefold, that is; to improve energy efficiency, to maximize the energy extracted from untreated water and eventually from sludge, and to recover other renewable energies. Energy recovered from sludge could be above $60 \%$ of the total energy needs of a sewage treatment plant. Besides, energy savings can be achieved:

-Innovative technologies in digester design, and sludge pre-treatment before digestion -Use of power generation and combined heat from digester gases electricity for various treatment needs.

-Direct use of gas after purification to the gas grid.

- Use of the biosolids in agriculture, and as a solid fuel in industry. Sludge contains numerous nutrients that can assist crop production provided that all precautions are applied. Improving treatment technological practices and following 'best practice' suggestions for low energy consumption can produce savings around $20 \%$. [1]. Energy recovered from sewage flows, improved topography designs to reduce pumping needs, as well as using other innovative technologies such as photovoltaic-thermal systems, wind turbines and others can produce considerable savings in energy to another $20 \%$.

\section{REFERENCES}

[1] Lazarova V., Choo K.H. and Cornel P. (2012). Water Energy interactions in water reuse. IWA Publishing, London, UK.

[2] Kathijotes N. (2013). Keynote: 'Blue Economy - Environmental and Behavioural Aspects towards Sustainable Coastal Development', Elsevier Procedia - Social and Behavioural Sciences, Volume 101, 2013, Pages 7-13 
[3] Novak O., Keil S., Fimml C. (2011), Examples of energy self-sufficient municipal nutrient removal plants. Water Science and Technology, 64(1) 1-6

[4] Voutchkov N. (2010), Seawater desalination: current trends and challenges. Desalination-Filtration + Separation Publication, 5(2), 4-7.

[5] European Commission Maritime Affairs, Blue Growth: Opportunities for marine and maritime sustainable growth, 2012. http://dx.doi.org/10.2771/ 43949.

[6] REN21, Renewables 2013 Global Status Report. Paris, 2013.

[7] G. Wright, Marine governance in an industrialised ocean: A case study of the emerging marine renewable energy industry, Mar. Policy 52 (2015) 77-84, http://dx.doi.org/10.1016/j.marpol.2014.10.021.

[8] S. Kerr, L. Watts, J. Colton, F. Conway, A. Hull, K. Johnson, S. Jude, A. Kannen, S Macdougall, C. Mclachlan, T. Potts, J. Vergunst, Establishing an agenda for social

[9] K. Johnson, S. Kerr, J. Side, Marine renewables and coastal communities-Experiences from the offshore oil industry in the 1970s and their relevance to marine renewables in the 2010s, Mar. Policy 38 (2013) 491-499, http://dx.doi. org/10.1016/j.marpol.2012.08.004.

[10] Maceiras R, Rodrí guez M, Cancela A, Urrejola S, Sanchez A. Macroalgae: raw material for biodiesel production. Appl Energy 2011;88:3318-23.

[11] Ross AB, Jones JM, Kubacki ML, Bridgeman T. Classification of macroalgae as fuel and its thermochemical behavior. Bioresour Technol 2008;99:6494-504.

[12] Plunkett JW. Plunkett's automobile industry almanac 2008: automobile, truck and speciality vehicle industry market research, statistics, trends \& leading companies. Houston (Texas): Plunkett Research Ltd.; 2007.

[13] World Business Council for Sustainable Development (WBCSD). Mobility 2030: meeting the challenges to sustainability. The sustainable mobility project. Geneva (Switzerland); 2004. 